\title{
Commentary: Cross circulation comes full circle (via lung transplantation)
}

\author{
Michael K. Hsin, MD
}

From the Department of Cardiothoracic Surgery, Queen Mary Hospital, Hong Kong, China.

Disclosures: Author has nothing to disclose with regard to commercial support.

Received for publication Sept 15, 2019; revisions received Sept 15, 2019; accepted for publication Sept 16, 2019 ; available ahead of print Oct 29, 2019.

Address for reprints: Michael K. Hsin, MD, Department of Cardiothoracic Surgery, Queen Mary Hospital, 102 Pok Fu Lam Rd, High West, Hong Kong, China (E-mail: mkhsin@ hotmail.com).

J Thorac Cardiovasc Surg 2020;159:1654-5

$0022-5223 / \$ 36.00$

Copyright (c) 2019 by The American Association for Thoracic Surgery

https://doi.org/10.1016/j.jtcvs.2019.09.045

In 1954, Lillehei reported the use of cross-circulation in the repair of a ventricular septal defect, which used the patient's father as the "oxygenator." At the time, the results of screen oxygenators were disappointing, and Lillehei's innovation made the repair of complex intracardiac defects feasible, thus ushering in the era of open heart surgery. ${ }^{1}$ Sixty-five years later, at the American Association for Thoracic Surgery's 99th annual meeting, the C. Walton Lillehei Residents' Award was given to Dr Ahmed Hozain from the Columbia and Vanderbilt group, whose work can be seen as a nod to the Lillehei procedure. In this issue of the Journal, Hozain and colleagues ${ }^{2}$ report the proof of feasibility study in a pig lung transplantation model in which the donor lungs were supported extracorporeally by cross circulation with the awake recipient for 4 days before transplantation.

The utilization of available cadaveric donor lungs is the worst among all solid organ transplants. This is because myriad factors, such as ventilator-acquired pneumonia, aspiration, and catecholamine release secondary to brain death, can cause injury to the potential donor's lungs. ${ }^{3}$ Ex vivo lung perfusion (EVLP) is an important advance that allows clinicians to evaluate the quality of borderline donor lungs objectively; with its use, a conversion rate as high as $80 \%$ has been reported, thus significantly increasing the utilization of donor lungs. ${ }^{4,5}$

EVLP has been proposed as a platform for treatment delivery to injured lungs. Thrombolysis of pulmonary embolism in the donor lung has been reported. ${ }^{6}$ Preclinical reports using gene therapy and cell therapy delivered during EVLP with perfusion time of 12 hours show promise ${ }^{7,8}$; however, reports of EVLP with a duration beyond 12 hours are sparse. ${ }^{9}$ This may be because the isolated single organ perfusion lacks the nutritional support and the mechanisms to remove metabolic waste products, therefore limiting the extension of perfusion duration.

The cross circulation concept described by Hozain and colleagues $^{2}$ may provide an alternative avenue to circumvent these limitations. With normothermic extracorporeal

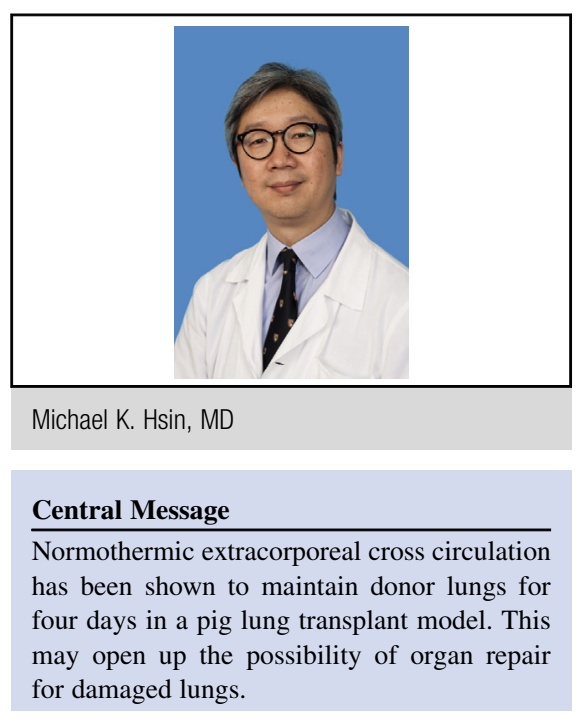

See Article page 1640 .

support that uses cross circulation with an awake "recipient," Hozain and colleagues ${ }^{2}$ envisage a system in which potential lung transplant recipients who are supported on extracorporeal membrane oxygenation may be connected to suboptimal donor lungs to enable recovery of these lungs. They further postulate that, because these donor lungs can be maintained for several days, this time frame opens up the possibility of cell therapy and bioengineering approaches for advanced organ repair.

This study is limited by (1) the small number of transplanted animals and (2) the use of healthy donor pig lungs for cross circulation and transplant. In addition to the demonstration of reproducibility, a reasonable next step is to consider the use of injured lungs for cross circulation, to clarify whether suboptimal donor lungs could indeed recover. Equally important is to demonstrate that cross circulation with damaged lungs does not cause deterioration in the recipient, for example because of the inflammatory cytokines or infection derived from the injured donor lungs.

The promise of extracorporeal repair of donor organs is indeed appealing, and Hozain and colleagues ${ }^{2}$ have provided a novel direction of investigation by making use of a concept first pioneered by Lillehei.

\section{References}

1. Lillehei CW, Varco RL, Cohen M, Warden HE, Patton C, Moller JH. The first open-heart repairs of ventricular septal defect, atrioventricular communis, and 
tetralogy of Fallot using extracorporeal circulation by cross-circulation: a 30-year follow-up. Ann Thorac Surg. 1986;41:4-21.

2. Hozain AE, Tipograf Y, Pinezich MR, Cunningham KM, Donocoff R, Queen D, et al. Multiday maintenance of extracorporeal lungs using cross-circulation with conscious swine. J Thorac Cardiovasc Surg. 2020;159:1640-53.e18.

3. de Perrot M, Liu M, Waddell TK, Keshavjee S. Ischemia-reperfusion-induced lung injury. Am J Respir Crit Care Med. 2003;167:490-511.

4. Cypel M, Yeung JC, Liu M, Anraku M, Chen F, Karolak W, et al. Normothermic ex vivo lung perfusion in clinical lung transplantation. N Engl J Med. 2011;364: $1431-40$.

5. Cypel M, Yeung JC, Machuca T, Chen M, Singer LG, Yasufuku K, et al. Experience with the first 50 ex vivo lung perfusions in clinical transplantation. J Thorac Cardiovasc Surg. 2012;144:1200-6.
6. Machuca TN, Hsin MK, Ott HC, Chen M, Hwang DM, Cypel M, et al. Injury-specific ex vivo treatment of the donor lung: pulmonary thrombolysis followed by successful lung transplantation. Am J Respir Crit Care Med. 2013;188:878-80.

7. Machuca TN, Cypel M, Bonato R, Yeung JC, Chun YM, Juvet S, et al. Safety and efficacy of ex vivo donor lung adenoviral IL-10 gene therapy in a large animal lung transplant survival model. Hum Gene Ther. 2017;28:757-65.

8. Nakajima D, Watanabe Y, Ohsumi A, Pipkin M, Chen M, et al. Mesenchymal stromal cell therapy during ex vivo lung perfusion ameliorates ischemiareperfusion injury in lung transplantation. J Heart Lung Transplant. July 26, 2019 [Epub ahead of print].

9. Sommer W, Salman J, Avsar M, Hoeffler K, Jansson K, Siemeni TN, et al. Prediction of transplant outcome after 24-hour ex vivo lung perfusion using the organ care system in a porcine lung transplantation model. Am J Transplant. 2019;19:345-55. 